\title{
THE CONSEQUENCES OF APOPTOSIS IN AUTOIMMUNITY
}

\author{
Ana Lleo, MD ${ }^{a, b}$, Carlo Selmi, MD PhDa,b, Pietro Invernizzi, MD PhD ${ }^{a, b}$, Mauro Podda, \\ $\mathbf{M D}^{\mathrm{b}}$, and $\mathbf{M}$. Eric Gershwin, $\mathbf{M D}^{\mathrm{a}}$ \\ a Division of Rheumatology, Allergy, and Clinical Immunology, University of California at Davis, Davis, CA, \\ USA \\ b Division of Internal Medicine and Liver Unit, San Paolo School of Medicine University of Milan, Milan, \\ Italy
}

\begin{abstract}
The clearance of apoptotic cells is a highly regulated mechanism, normally associated with antiinflammatory response. During early stages of apoptosis the cell is promptly recognized and engulfed by professional phagocytes or tissue cells to avoid the outflow of intracellular content and limit the immunological reaction against released antigens. However, increasing evidences suggest that impairment in the uptake of apoptotic cell debris is linked to the development of autoimmunity. In fact, autoantigens have been demonstrated to be content within apoptotic bodies and apoptotic cells seems to be critical in the presentation of antigens, activation of innate immunity and regulation of macrophage cytokine secretion.
\end{abstract}

We herein review the known mechanisms for regulating the uptake of the products of apoptosis in the development of autoimmunity.

\section{Keywords}

Cell clearance; lupus; autoantibodies

\section{INTRODUCTION}

Apoptosis, the major mechanism of programmed cell death, is essential to regulate and maintain tissue growth and maintain homeostasis. Dying cells undergo morphological modifications including chromatin condensation, nuclear fragmentation and generation of apoptotic bodies. Furthermore, they express so called "eat-me" signals on the cell surface that allow macrophage recognition and phagocytosis [1]. Thus, apoptosis is no longer considered a "trash disposal" mechanism as the clearance of apoptotic cells is a highly regulated process, essential to avoid the outflow of intracellular content and limit the immunological response against generated antigens. Within the immune system alone, it has been estimated that more than $10^{9}$ cells undergo apoptosis daily [2] and these are cleared rapidly by neighboring tissue cells or professional phagocytes, normally without inciting an inflammatory reaction [3-5]. Indeed, the most significant difference between phagocytosis of pathogens and the uptake of

Corresponding author: M. Eric Gershwin MD, Division of Rheumatology, Allergy and Clinical Immunology, University of California at Davis School of Medicine, Genome and Biomedical Sciences Facility, 451 E Health Sciences Drive, suite 6510, Davis, CA 95616; Telephone: 530-752-2884; Fax: 530-752-4669; email: megershwin@ucdavis.edu.

Publisher's Disclaimer: This is a PDF file of an unedited manuscript that has been accepted for publication. As a service to our customers we are providing this early version of the manuscript. The manuscript will undergo copyediting, typesetting, and review of the resulting proof before it is published in its final citable form. Please note that during the production process errors may be discovered which could affect the content, and all legal disclaimers that apply to the journal pertain. 
apoptotic cells has been traditionally considered the immune response: a pro-inflammatory reaction is often induced after phagocytosis whereas the secretion of anti-inflammatory cytokines follows the engulfment of apoptotic cells $[4,6,7]$.

Dysregulation of apoptosis has been associated with the pathogenesis of cancer [8,9], neurodegeneration [10], cardiovascular disease [11,12], and other complex diseases. The impact of apoptosis on immunity has been extensively investigated $[2,13]$ and several reports suggest a correlation between apoptosis and autoimmunity through an impairment of apoptosis [14-16] or an ineffective removal of apoptotic cells [17-20]. Moreover, recent data have demonstrated that autoantigens are found within apoptotic bodies [21] and that apoptotic cells are critical in the presentation of antigens [22], activation of innate immunity and regulation of macrophage cytokine secretion [23]. Apoptotic bodies have been also described as B cell autoantigens [24]. This review article is intended to provide a critical overview of current theories on the consequences of apoptosis and their connection to the breakdown of tolerance.

\section{CLEARANCE OF APOPTOTIC CELLS AND PRODUCTS}

The removal of apoptotic cells is mediated by professional phagocytes, i.e. macrophages and immature dendritic cells (DC) $[25,26]$, and by a wide variety of cells, such as endothelial cells [27], mesenchymal cells [28], or cardiocytes [17]. Professional phagocytes can also ingest opsonized bacteria or pathogens; however, the process and the consequences of these processes are distinct. The most important difference between the up-take of apoptotic cells and the phagocytosis of pathogens is the immune response, and the term engulfment is used to define the uptake of apoptotic cells (Table 1) [1]. Differences in the mechanisms of uptake between professional phagocytes and tissue cells have been reported [29]; these appear to reflect the rates of uptake and the timing of digestion rather than unique uptake mechanisms, receptors and signaling.

It is generally accepted that the uptake of apoptotic cells involves four essential steps (Figure 1): the release of "find me" signals that advise the phagocytes of the presence of apoptotic cells; the expression of "eat me" signals and recognition of the apoptotic cells by the phagocyte; the cytoskeletal reorganization and internalization of the target; and the degradation of the ingested apoptotic cell.

At the earliest stages of apoptosis, dying cells release diffusible factors, known as 'find-me' signals, which facilitate the recruitment of phagocytes. Lauber et al demonstrated that the lipid lysolysophosphatidylcholine (LPC), a factor released by apoptotic cells, can attract monocytes [30]. The regulation of this signals and the response induced in the phagocytes are still unknown. Apoptotic cells then express "eat me" signals on the cellular surface in the early stages of apoptosis [13] to allow phagocytic recognition. Several receptors have been reported to mediate the binding and uptake of dying cells, the most studied of these factors is phosphatidylserine (PtdSer) [31,32]. In addition, the phagocytes express receptors that recognize the "eat-me" signals, i.e. the PtdSer-specific receptor [33-35]. The expression of the "eat-me" signals appears to be cell specific and to depend on the coexistence of multiple factors, i.e. by which cell is being engulfed, the receptors that are expressed by the apoptotic cell, the state of activation of the phagocyte [36,37]. There is also evidence that inhibitors ("don't eat me" signals) play a role in this process and in its regulation [38]. Finally, to be able to engulf the apoptotic cell the phagocyte requires an actin-dependent cytoskeletal reorganization that involves two signaling pathways: first, the RHO family GTPases, with a fine balance between activating (i.e. RAC) and inhibiting factors (i.e. RHOA) [39]; the second pathway involves the cell surface receptor proteins ABC1/CED-7 and CD-91/CED-1 [40]. After internalization, actin is displaced from the phagosome and the phagosome matures by a series of fusion and fission events with components of the endocytic pathway culminating in the mature 
phagolysosome. Phagosome trafficking occurs primarily in association with microtubules and therefore requires the coordinated interaction of the actin- and tubulin-based cytoskeleton. The final step of the engulfment of apoptotic cells is the digestion, and importantly, the consequences that the process determines in the cytokine secretion.

The absence of pro-inflammatory response after ingestion of apoptotic cells is considered one of the key points of the engulfment of dying cells [41]. In fact, it has been demonstrated that monocyte secretion of IL-1 $\beta$, IL-8, granulocyte macrophage colony-stimulating factor, and TNF- $\alpha$ is inhibited after phagocytosis of apoptotic cells whereas the secretion of antiinflammatory cytokines such as TGF- $\beta 1$ and IL-10 is increased [7,42]; interestingly these data have been also confirmed in vivo [6]. However, it is well accepted that impaired clearance of apoptotic cells is related to the development of autoimmunity and promote the secretion of proinflammatory cytokines [43]. A recent study seems to clarify in part this paradox [17]. In congenital heart block (CHB) in infants from anti-Ro positive mothers the opsonization of apoptotic cells with maternal antibodies inhibits the clearance of apoptotic cells with consequent accumulation and production of inflammatory cytokines.

In conclusion, the role of apoptotic cells in the development of autoimmunity seems to be in part related to a defect in their clearance, with consequent impairment of the balance of signals associated to the apoptotic cell ingestion, i.e "eat me" signals [13], the phagocytic cell itself and how long the apoptotic cells persists before and after phagocytosis occurs (Figure 2).

\section{THE ADAPTIVE IMMUNE RESPONSE TO APOPTOTIC CELLS}

\section{Antigen presentation}

A key factor in the induction of immune responses is the ability of DCs to internalize antigens and present antigen-derived peptides on major histocompatibility complex (MHC) molecules for the recognition by $\mathrm{T}$ lymphocytes.

Albert et al reported that immature DC are capable of phagocytosis of apoptotic cells, although not as efficiently as macrophages $[25,44]$ and that they can cross-present viral, tumor, and selfantigens to CD8+ T cells [45]. Moreover, it was recently suggested that apoptotic cells are able to promote maturation of DCs by upregulating costimulatory molecules and inducing proinflammatory cytokine release, while functioning as endogenous adjuvants for the induction of specific T cell responses [46]. Further evidence supporting the presentation of neo-antigens derived from apoptotic cells by DCs has been reported [47-49]. Nevertheless, the issue remains unclear and it has also been demonstrated that the uptake of apoptotic cells by DC suppresses the secretion of IL-12, a paracrine agent that alters the maturation of the DC, resulting in the inability to activate $\mathrm{T}$ cells [13]. These discrepancies may be due to the type of apoptotic cell being used, the variable effects of early and late stage apoptotic cells on DC maturation [50], and cytokine secretion [51].

Interestingly, DCs have a limited capacity for lysosomal degradation, due to a poor content of lysosomal protease [52] and apoptotic cells contained in DC phagosomes have been observed in the afferent lymphatics of the intestine directed to the lymphonodes [53]. On this basis, it has been suggested that the slow degradation of ingested apoptotic material by DC may allow an extended period of time to sample the microenvironment for danger signals, which stimulate DC to initiate an immune response [54]. Danger signals include those received through pattern recognition receptors such as Toll-like receptors (TLR) but also necrotic cells [55].

\section{T cells}

The first report of antigens expressed by apoptotic cells that were presented to T cells [45, 56] was published almost ten years ago. At the same time, T cell proliferation in PBMC isolated 
from both healthy controls or patients with systemic lupus erythematosus (SLE) was induced using either apoptotic cells or isolated antigens [57]; cloning of these T cells confirmed that antoantigens typically found in SLE, i.e. histones, were targeted by some of these T cell clones. Since then it has became generally accepted that antigens generated or exposed during apoptosis can lead the production of autoreactive T cells [13,58]. It is known that the engulfment of necrotic cells strongly stimulate DC to mature and activate T cells; intracellular proteins also activate DC [59] suggesting that cells must lyse before they can promote an immune response. It has been then hypothesized that the autoimmune response is a consequence of the uptake of late apoptotic cells. In fact, phagocytosis of late apoptotic cells by mouse macrophages leads to the production of proinflammatory cytokines [60]. However, this theory is in contrast with the recent report that autoantigens are translocated into small apoptotic bodies during the early stages of apoptosis [21].

\section{B cells}

It has been proposed that apoptotic bodies can be targeted by autoantibodies [24] and that B cells with Ig receptors for apoptotic cells are positively selected [61]. Accordingly, B cells that react with apoptotic cells may tip the balance from tolerance to autoimmunity (Figure 2).

\section{THE CONSEQUENCES OF APOPTOSIS IN AUTOIMMUNE DISEASES}

It has been demonstrated that dysregulated apoptosis or impaired clearance of dying cells is related to the development of autoimmune diseases. However, most of the data on apoptosis in these conditions derives from observations and the pathogenic role of apoptosis remains to be established. Three different processes involving apoptotic cells have been demonstrated to be related to the development of autoimmunity. First, apoptosis is the mode of cell killing by immune processes e.g. cytotoxic $\mathrm{T}$ lymphocyte; it can make autoantigens available for selfperpetuating disease. Second, apoptosis in excess can be a source of autoimunogenic fragments, as discussed here in the context of neonatal lupus syndromes. Finally, genetic faults in apoptosis pathways, prototypically Fas/FasL, can interfere with tolerogenic deletion of lymphocytes and facilitate autoimmunity, a typical example of this is the autoimmune lymphoproliferative syndrome.

Table 2 summarizes the available data about the consequences of apoptosis in autoimmune diseases

\section{Systemic Lupus Erythematosus (SLE)}

The complement protein C1q has been a focus of attention in SLE for many years, since C1q is consumed during acute phases of the disease [62]. In recent years, C1q has taken on greater importance, since it has been implicated in the effective removal of apoptotic products [63]. Several experimental reports demonstrate the relationship between impaired clearance of apoptotic cells and SLE, and especially the involvement of C1q defects in SLE [64]. Kalaaji et al demonstrated that large chromatin fragments, derived from apoptotic cells, localize in the intraglomerular membrane in murine and human SLE [65], and that those intra-glomerular membrane-associated nucleosomes are targeted by anti-dsDNA autoantibodies in human lupus nephritis [66].

Neonatal lupus syndromes (NLS) affect a variety of different organs; the most relevant involvement is represented by the heart, but also disorders of the skin, liver, and blood elements are all linked with anti-SSA/Ro-SSB/La antibodies in the maternal and fetal circulation [67, 68]. The $\mathrm{CHB}$ is a rare condition caused by inflammatory degeneration of the myocardic conductive system in infants from anti-Ro positive mothers, with SLE or Sjögren syndrome. This disease is of special interest for the understanding of the role of apoptosis in the 
development of autoimmune diseases. It has been demonstrated that maternal autoantibodies pass through the placental filter and recognize antigens expressed within the blebs of apoptotic cardiocytes. Interestingly, the opsonization of blebs with maternal autoantibodies inhibits the macrophage clearance with consequent accumulation and production of inflammatory cytokines $[17,69,70]$.

\section{Autoimmune lymphoproliferative syndrome (ALPS)}

ALPS is a rare defect in lymphocyte apoptosis that alters immune homeostasis resulting in an expansion of a normally rare circulating lymphocyte, the $\alpha \beta$ double negative T cell. ALPS is associated with inherited heterozygous mutations in the Fas gene that serves as a risk factor for autoimmunity involving blood cells and the development of lymphoma [71].

\section{Primary biliary cirrhosis (PBC)}

A characteristic feature of PBC is the specificity of the immune damage on the small intrahepatic bile ducts, despite the fact that the mitochondrial targets are ubiquitous proteins expressed in all nucleated cells. About $90 \%$ of patients with $\mathrm{PBC}$ have serum antimitochondrial antibodies (AMA) against the E2 subunit of the mitochondrial pyruvate dehydrogenase complex (PDC-E2). An anomaly of apoptosis in biliary epithelial cells (BEC) has been hypothesized as a source of antigens that could be responsible for activation of autoreactive $\mathrm{T}$ cells. It is known that macrophage phagocytosis of opsonized apoptotic cells is delayed in PBC [19] and that oxidative stress [16] induce apoptosis in BEC. However, how the mitochondrial antigens ultimate become exposed to the immune system is still unknown. In apoptotic BECs PDC-E2 is released not modified, whereas other cell types loose the antigenicity of PDC-E2 during apoptosis [72]; this seems to be related to lack of glutathiolation of PDC-E2 in BECs, since glutathiolation prevents autoantibody recognition [72]. Furthemore, BECs have the ability to phagocyte apoptotic BECS and to present novel mitochondrial self-peptides derived from phagocytosed apoptotic BECs [18]. These data support the hypothesis that phagocytosis of apoptotic cell by non-professional phagocytes may contribute to the tissue specificity of autoimmune diseases. Finally, Shimoda el al have recently suggested that BECs are "innocent victims" of autoimmune injury and that the proinflammatory activity of BECs in PBC is secondary to the intervention of liver-infiltrating mononuclear cells [73].

\section{CONCLUSIONS AND FUTURE DIRECTIONS}

The clearance of apoptotic cells, initially seen as an uninteresting "waste disposal", is now accepted as a multipurpose process that is critical to the maintenance of tolerance; indeed, the removal of cellular components potentially antigenic is generally immunologically silent. One of the major issues in autoimmunity has been the intracellular localization of many autoantigens and how these molecules may become exposed to the immune system. An impairment in the clearance of apoptotic cells may resolve this issue. However, there are still contradictions to resolve: how does the anti-inflammatory response that follows the uptake of apoptotic cells become pro-inflammatory? What is the role of DC in the presentation of new antigens? How can we reconcile DC's suppressive response to ingested apoptotic cells with their role of antigen presenting cells of neoantigens? What are the genetic and environmental factors that regulate apoptosis and antigen cleavage?

Nevertheless, we recognize the exciting prospect that the molecular identification of the factors that promote the initiation and the maintenance of normal apoptosis could provide novel tools for effective and possibly less toxic therapeutic interventions in patients with autoimmune diseases. 
ABBREVIATIONS

DC

dendritic cells

MHC

major histocompatibility complex

SLE

systemic lupus erythematosus

CHB

congenital heart block

ALPS

autoimmune lymphoproliferative syndrome

LN

lupus nephritis

\section{References}

1. Ravichandran KS, Lorenz U. Engulfment of apoptotic cells: signals for a good meal. Nat Rev Immunol 2007;7:964-974. [PubMed: 18037898]

2. Peng Y, Martin DA, Kenkel J, Zhang K, Ogden CA, Elkon KB. Innate and adaptive immune response to apoptotic cells. J Autoimmun 2007;29:303-309. [PubMed: 17888627]

3. Kurosaka K, Takahashi M, Watanabe N, Kobayashi Y. Silent cleanup of very early apoptotic cells by macrophages. J Immunol 2003;171:4672-4679. [PubMed: 14568942]

4. Voll RE, Herrmann M, Roth EA, Stach C, Kalden JR, Girkontaite I. Immunosuppressive effects of apoptotic cells. Nature 1997;390:350-351. [PubMed: 9389474]

5. Henson PM. Dampening inflammation. Nat Immunol 2005;6:1179-1181. [PubMed: 16369556]

6. Huynh ML, Fadok VA, Henson PM. Phosphatidylserine-dependent ingestion of apoptotic cells promotes TGF-beta1 secretion and the resolution of inflammation. J Clin Invest 2002;109:41-50. [PubMed: 11781349]

7. Fadok VA, Bratton DL, Konowal A, Freed PW, Westcott JY, Henson PM. Macrophages that have ingested apoptotic cells in vitro inhibit proinflammatory cytokine production through autocrine/ paracrine mechanisms involving TGF-beta, PGE2, and PAF. J Clin Invest 1998;101:890-898. [PubMed: 9466984]

8. Youle RJ, Strasser A. The BCL-2 protein family: opposing activities that mediate cell death. Nat Rev Mol Cell Biol 2008;9:47-59. [PubMed: 18097445]

9. Condeelis J, Pollard JW. Macrophages: obligate partners for tumor cell migration, invasion, and metastasis. Cell 2006;124:263-266. [PubMed: 16439202]

10. Leuner K, Pantel J, Frey C, Schindowski K, Schulz K, Wegat T, et al. Enhanced apoptosis, oxidative stress and mitochondrial dysfunction in lymphocytes as potential biomarkers for Alzheimer's disease. J Neural Transm Suppl 2007:207-215. [PubMed: 17982897]

11. Choudhury RP, Lee JM, Greaves DR. Mechanisms of disease: macrophage-derived foam cells emerging as therapeutic targets in atherosclerosis. Nat Clin Pract Cardiovasc Med 2005;2:309-315. [PubMed: 16265535]

12. Hahn BH, Grossman J, Chen W, McMahon M. The pathogenesis of atherosclerosis in autoimmune rheumatic diseases: roles of inflammation and dyslipidemia. J Autoimmun 2007;28:69-75. [PubMed: 17433865]

13. Savill J, Dransfield I, Gregory C, Haslett C. A blast from the past: clearance of apoptotic cells regulates immune responses. Nat Rev Immunol 2002;2:965-975. [PubMed: 12461569] 
14. Perniok A, Wedekind F, Herrmann M, Specker C, Schneider M. High levels of circulating early apoptic peripheral blood mononuclear cells in systemic lupus erythematosus. Lupus 1998;7:113118. [PubMed: 9541096]

15. Ruiz-Arguelles A, Brito GJ, Reyes-Izquierdo P, Perez-Romano B, Sanchez-Sosa S. Apoptosis of melanocytes in vitiligo results from antibody penetration. J Autoimmun 2007;29:281-286. [PubMed: 17888626]

16. Salunga TL, Cui ZG, Shimoda S, Zheng HC, Nomoto K, Kondo T, et al. Oxidative stress-induced apoptosis of bile duct cells in primary biliary cirrhosis. J Autoimmun 2007;29:78-86. [PubMed: 17544621]

17. Clancy RM, Neufing PJ, Zheng P, O’Mahony M, Nimmerjahn F, Gordon TP, et al. Impaired clearance of apoptotic cardiocytes is linked to anti-SSA/Ro and -SSB/La antibodies in the pathogenesis of congenital heart block. J Clin Invest 2006;116:2413-2422. [PubMed: 16906225]

18. Allina J, Hu B, Sullivan DM, Fiel MI, Thung SN, Bronk SF, et al. T cell targeting and phagocytosis of apoptotic biliary epithelial cells in primary biliary cirrhosis. J Autoimmun 2006;27:232-241. [PubMed: 17222534]

19. Allina J, Stanca CM, Garber J, Hu B, Sautes-Fridman C, Bach N, et al. Anti-CD16 autoantibodies and delayed phagocytosis of apoptotic cells in primary biliary cirrhosis. J Autoimmun. 2007

20. Lleo A, Invernizzi P, Selmi C, Coppel RL, Alpini G, Podda M, et al. Autophagy: highlighting a novel player in the autoimmunity scenario. J Autoimmun 2007;29:61-68. [PubMed: 17693057]

21. Schiller M, Bekeredjian-Ding I, Heyder P, Blank N, Ho AD, Lorenz HM. Autoantigens are translocated into small apoptotic bodies during early stages of apoptosis. Cell Death Differ 2008;15:183-191. [PubMed: 17932498]

22. Mandron M, Martin H, Bonjean B, Lule J, Tartour E, Davrinche C. Dendritic cell-induced apoptosis of human cytomegalovirus-infected fibroblasts promotes cross-presentation of pp65 to CD8+ T cells. J Gen Virol 2008;89:78-86. [PubMed: 18089731]

23. Lucas M, Stuart LM, Savill J, Lacy-Hulbert A. Apoptotic cells and innate immune stimuli combine to regulate macrophage cytokine secretion. J Immunol 2003;171:2610-2615. [PubMed: 12928413]

24. Cocca BA, Cline AM, Radic MZ. Blebs and apoptotic bodies are B cell autoantigens. J Immunol 2002;169:159-166. [PubMed: 12077241]

25. Albert ML, Pearce SF, Francisco LM, Sauter B, Roy P, Silverstein RL, et al. Immature dendritic cells phagocytose apoptotic cells via alphavbeta5 and CD36, and cross-present antigens to cytotoxic T lymphocytes. J Exp Med 1998;188:1359-1368. [PubMed: 9763615]

26. Lang KS, Burow A, Kurrer M, Lang PA, Recher M. The role of the innate immune response in autoimmune disease. J Autoimmun 2007;29:206-212. [PubMed: 17904335]

27. Dini L, Lentini A, Diez GD, Rocha M, Falasca L, Serafino L, et al. Phagocytosis of apoptotic bodies by liver endothelial cells. J Cell Sci 1995;108(Pt 3):967-973. [PubMed: 7622623]

28. Wood W, Turmaine M, Weber R, Camp V, Maki RA, McKercher SR, et al. Mesenchymal cells engulf and clear apoptotic footplate cells in macrophageless PU.1 null mouse embryos. Development 2000;127:5245-5252. [PubMed: 11076747]

29. Parnaik R, Raff MC, Scholes J. Differences between the clearance of apoptotic cells by professional and non-professional phagocytes. Curr Biol 2000;10:857-860. [PubMed: 10899007]

30. Lauber K, Bohn E, Krober SM, Xiao YJ, Blumenthal SG, Lindemann RK, et al. Apoptotic cells induce migration of phagocytes via caspase-3-mediated release of a lipid attraction signal. Cell 2003;113:717-730. [PubMed: 12809603]

31. Fadok VA, Voelker DR, Campbell PA, Cohen JJ, Bratton DL, Henson PM. Exposure of phosphatidylserine on the surface of apoptotic lymphocytes triggers specific recognition and removal by macrophages. J Immunol 1992;148:2207-2216. [PubMed: 1545126]

32. Fadok VA, Bratton DL, Rose DM, Pearson A, Ezekewitz RA, Henson PM. A receptor for phosphatidylserine-specific clearance of apoptotic cells. Nature 2000;405:85-90. [PubMed: 10811223]

33. Ezekowitz RA, Sastry K, Bailly P, Warner A. Molecular characterization of the human macrophage mannose receptor: demonstration of multiple carbohydrate recognition-like domains and phagocytosis of yeasts in Cos-1 cells. J Exp Med 1990;172:1785-1794. [PubMed: 2258707] 
34. Savill J, Dransfield I, Hogg N, Haslett C. Vitronectin receptor-mediated phagocytosis of cells undergoing apoptosis. Nature 1990;343:170-173. [PubMed: 1688647]

35. Gordon S. Macrophage-restricted molecules: role in differentiation and activation. Immunol Lett 1999;65:5-8. [PubMed: 10065619]

36. Obeid M, Tesniere A, Ghiringhelli F, Fimia GM, Apetoh L, Perfettini JL, et al. Calreticulin exposure dictates the immunogenicity of cancer cell death. Nat Med 2007;13:54-61. [PubMed: 17187072]

37. Pradhan D, Krahling S, Williamson P, Schlegel RA. Multiple systems for recognition of apoptotic lymphocytes by macrophages. Mol Biol Cell 1997;8:767-778. [PubMed: 9168465]

38. Brown S, Heinisch I, Ross E, Shaw K, Buckley CD, Savill J. Apoptosis disables CD31-mediated cell detachment from phagocytes promoting binding and engulfment. Nature 2002;418:200-203. [PubMed: 12110892]

39. Ridley AJ. Rho family proteins: coordinating cell responses. Trends Cell Biol 2001;11:471-477. [PubMed: 11719051]

40. Zhou Z, Hartwieg E, Horvitz HR. CED-1 is a transmembrane receptor that mediates cell corpse engulfment in C. elegans. Cell 2001;104:43-56. [PubMed: 11163239]

41. Meagher LC, Savill JS, Baker A, Fuller RW, Haslett C. Phagocytosis of apoptotic neutrophils does not induce macrophage release of thromboxane B2. J Leukoc Biol 1992;52:269-273. [PubMed: 1522386]

42. Byrne A, Reen DJ. Lipopolysaccharide induces rapid production of IL-10 by monocytes in the presence of apoptotic neutrophils. J Immunol 2002;168:1968-1977. [PubMed: 11823533]

43. Gaipl US, Munoz LE, Grossmayer G, Lauber K, Franz S, Sarter K, et al. Clearance deficiency and systemic lupus erythematosus (SLE). J Autoimmun 2007;28:114-121. [PubMed: 17368845]

44. Rubartelli A, Poggi A, Zocchi MR. The selective engulfment of apoptotic bodies by dendritic cells is mediated by the alpha(v)beta3 integrin and requires intracellular and extracellular calcium. Eur J Immunol 1997;27:1893-1900. [PubMed: 9295024]

45. Albert ML, Sauter B, Bhardwaj N. Dendritic cells acquire antigen from apoptotic cells and induce class I-restricted CTLs. Nature 1998;392:86-89. [PubMed: 9510252]

46. Johansson U, Walther-Jallow L, Smed-Sorensen A, Spetz AL. Triggering of dendritic cell responses after exposure to activated, but not resting, apoptotic PBMCs. J Immunol 2007;179:1711-1720. [PubMed: 17641037]

47. Rovere P, Manfredi AA, Vallinoto C, Zimmermann VS, Fascio U, Balestrieri G, et al. Dendritic cells preferentially internalize apoptotic cells opsonized by anti-beta2-glycoprotein I antibodies. J Autoimmun 1998;11:403-411. [PubMed: 9802923]

48. Frisoni L, McPhie L, Colonna L, Sriram U, Monestier M, Gallucci S, et al. Nuclear autoantigen translocation and autoantibody opsonization lead to increased dendritic cell phagocytosis and presentation of nuclear antigens: a novel pathogenic pathway for autoimmunity? J Immunol 2005;175:2692-2701. [PubMed: 16081846]

49. Tzeng TC, Suen JL, Chiang BL. Dendritic cells pulsed with apoptotic cells activate self-reactive Tcells of lupus mice both in vitro and in vivo. Rheumatology (Oxford) 2006;45:1230-1237. [PubMed: 16595513]

50. Ip WK, Lau YL. Distinct maturation of, but not migration between, human monocyte-derived dendritic cells upon ingestion of apoptotic cells of early or late phases. J Immunol 2004;173:189196. [PubMed: 15210774]

51. Bondanza A, Zimmermann VS, Dell'Antonio G, Cin ED, Balestrieri G, Tincani A, et al. Requirement of dying cells and environmental adjuvants for the induction of autoimmunity. Arthritis Rheum 2004;50:1549-1560. [PubMed: 15146425]

52. Delamarre L, Pack M, Chang H, Mellman I, Trombetta ES. Differential lysosomal proteolysis in antigen-presenting cells determines antigen fate. Science 2005;307:1630-1634. [PubMed: 15761154]

53. Huang FP, Platt N, Wykes M, Major JR, Powell TJ, Jenkins CD, et al. A discrete subpopulation of dendritic cells transports apoptotic intestinal epithelial cells to T cell areas of mesenteric lymph nodes. J Exp Med 2000;191:435-444. [PubMed: 10662789]

54. Erwig LP, Henson PM. Immunological consequences of apoptotic cell phagocytosis. Am J Pathol 2007;171:2-8. [PubMed: 17591947] 
55. Sauter B, Albert ML, Francisco L, Larsson M, Somersan S, Bhardwaj N. Consequences of cell death: exposure to necrotic tumor cells, but not primary tissue cells or apoptotic cells, induces the maturation of immunostimulatory dendritic cells. J Exp Med 2000;191:423-434. [PubMed: 10662788]

56. Barker RN, Erwig LP, Hill KS, Devine A, Pearce WP, Rees AJ. Antigen presentation by macrophages is enhanced by the uptake of necrotic, but not apoptotic, cells. Clin Exp Immunol 2002;127:220225. [PubMed: 11876743]

57. Voll RE, Roth EA, Girkontaite I, Fehr H, Herrmann M, Lorenz HM, et al. Histone-specific Th0 and Th1 clones derived from systemic lupus erythematosus patients induce double-stranded DNA antibody production. Arthritis Rheum 1997;40:2162-2171. [PubMed: 9416853]

58. Bellone M, Iezzi G, Rovere P, Galati G, Ronchetti A, Protti MP, et al. Processing of engulfed apoptotic bodies yields T cell epitopes. J Immunol 1997;159:5391-5399. [PubMed: 9548479]

59. Grolleau A, Misek DE, Kuick R, Hanash S, Mule JJ. Inducible expression of macrophage receptor Marco by dendritic cells following phagocytic uptake of dead cells uncovered by oligonucleotide arrays. J Immunol 2003;171:2879-2888. [PubMed: 12960310]

60. Xiao YQ, Someya K, Morita H, Takahashi K, Ohuchi K. Involvement of p38 MAPK and ERK/MAPK pathways in staurosporine-induced production of macrophage inflammatory protein-2 in rat peritoneal neutrophils. Biochim Biophys Acta 1999;1450:155-163. [PubMed: 10354507]

61. Cocca BA, Seal SN, D'Agnillo P, Mueller YM, Katsikis PD, Rauch J, et al. Structural basis for autoantibody recognition of phosphatidylserine-beta 2 glycoprotein I and apoptotic cells. Proc Natl Acad Sci U S A 2001;98:13826-13831. [PubMed: 11717440]

62. Walport MJ, Davies KA, Botto M. C1q and systemic lupus erythematosus. Immunobiology 1998;199:265-285. [PubMed: 9777411]

63. Vandivier RW, Ogden CA, Fadok VA, Hoffmann PR, Brown KK, Botto M, et al. Role of surfactant proteins A, D, and C1q in the clearance of apoptotic cells in vivo and in vitro: calreticulin and CD91 as a common collectin receptor complex. J Immunol 2002;169:3978-3986. [PubMed: 12244199]

64. Donnelly S, Roake W, Brown S, Young P, Naik H, Wordsworth P, et al. Impaired recognition of apoptotic neutrophils by the $\mathrm{C} 1 \mathrm{q} /$ calreticulin and CD91 pathway in systemic lupus erythematosus. Arthritis Rheum 2006;54:1543-1556. [PubMed: 16645988]

65. Kalaaji M, Mortensen E, Jorgensen L, Olsen R, Rekvig OP. Nephritogenic lupus antibodies recognize glomerular basement membrane-associated chromatin fragments released from apoptotic intraglomerular cells. Am J Pathol 2006;168:1779-1792. [PubMed: 16723695]

66. Kalaaji M, Fenton KA, Mortensen ES, Olsen R, Sturfelt G, Alm P, et al. Glomerular apoptotic nucleosomes are central target structures for nephritogenic antibodies in human SLE nephritis. Kidney Int 2007;71:664-672. [PubMed: 17332738]

67. Izmirly PM, Rivera TL, Buyon JP. Neonatal lupus syndromes. Rheum Dis Clin North Am 2007;33:267-285. vi. [PubMed: 17499707]

68. Friedman DM, Rupel A, Buyon JP. Epidemiology, etiology, detection, and treatment of autoantibodyassociated congenital heart block in neonatal lupus. Curr Rheumatol Rep 2007;9:101-108. [PubMed: 17502039]

69. Clancy RM, Kapur RP, Molad Y, Askanase AD, Buyon JP. Immunohistologic evidence supports apoptosis, IgG deposition, and novel macrophage/fibroblast crosstalk in the pathologic cascade leading to congenital heart block. Arthritis Rheum 2004;50:173-182. [PubMed: 14730614]

70. Neufing PJ, Clancy RM, Jackson MW, Tran HB, Buyon JP, Gordon TP. Exposure and binding of selected immunodominant La/SSB epitopes on human apoptotic cells. Arthritis Rheum 2005;52:3934-3942. [PubMed: 16320341]

71. Sneller MC, Wang J, Dale JK, Strober W, Middelton LA, Choi Y, et al. Clincal, immunologic, and genetic features of an autoimmune lymphoproliferative syndrome associated with abnormal lymphocyte apoptosis. Blood 1997;89:1341-1348. [PubMed: 9028957]

72. Odin JA, Huebert RC, Casciola-Rosen L, LaRusso NF, Rosen A. Bcl-2-dependent oxidation of pyruvate dehydrogenase-E2, a primary biliary cirrhosis autoantigen, during apoptosis. J Clin Invest 2001;108:223-232. [PubMed: 11457875]

73. Shimoda S, Harada K, Niiro H, Yoshizumi T, Soejima Y, Taketomi A, et al. Biliary epithelial cells and primary biliary cirrhosis: The role of liver-infiltrating mononuclear cells. Hepatology. 2008 
74. Tran HB, Macardle PJ, Hiscock J, Cavill D, Bradley J, Buyon JP, et al. Anti-La/SSB antibodies transported across the placenta bind apoptotic cells in fetal organs targeted in neonatal lupus. Arthritis Rheum 2002;46:1572-1579. [PubMed: 12115188]

75. Zykova SN, Seredkina NE, Rekvig OP. Glomerular targets for autoantibodies in lupus nephritis--an apoptotic origin. Ann N Y Acad Sci 2007;1108:1-10. [PubMed: 17893965]

76. Bendiksen S, Mortensen ES, Olsen R, Fenton KA, Kalaaji M, Jorgensen L, et al. Glomerular expression of large polyomavirus $\mathrm{T}$ antigen in binary tet-off regulated transgenic mice induces apoptosis, release of chromatin and initiates a lupus-like nephritis. Mol Immunol 2008;45:728-739. [PubMed: 17719634]

77. Stassi G, De Maria R. Autoimmune thyroid disease: new models of cell death in autoimmunity. Nat Rev Immunol 2002;2:195-204. [PubMed: 11913070]

78. Stassi G, Di Liberto D, Todaro M, Zeuner A, Ricci-Vitiani L, Stoppacciaro A, et al. Control of target cell survival in thyroid autoimmunity by $\mathrm{T}$ helper cytokines via regulation of apoptotic proteins. Nat Immunol 2000;1:483-488. [PubMed: 11101869]

79. Wang SH, Baker JR. The role of apoptosis in thyroid autoimmunity. Thyroid 2007;17:975-979. [PubMed: 17900237]

80. Savinov AY, Tcherepanov A, Green EA, Flavell RA, Chervonsky AV. Contribution of Fas to diabetes development. Proc Natl Acad Sci U S A 2003;100:628-632. [PubMed: 12525697]

81. Chandra J, Zhivotovsky B, Zaitsev S, Juntti-Berggren L, Berggren PO, Orrenius S. Role of apoptosis in pancreatic beta-cell death in diabetes. Diabetes 2001;50(Suppl 1):S44-47. [PubMed: 11272200]

82. Pender MP. Treating autoimmune demyelination by augmenting lymphocyte apoptosis in the central nervous system. J Neuroimmunol 2007;191:26-38. [PubMed: 17931708] 


\section{1. "Find me" signals}

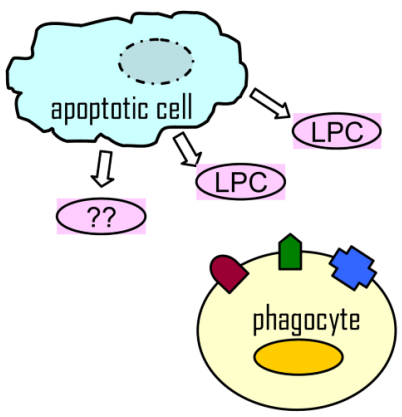

\section{Cytoskeletal reorganization and internalization}

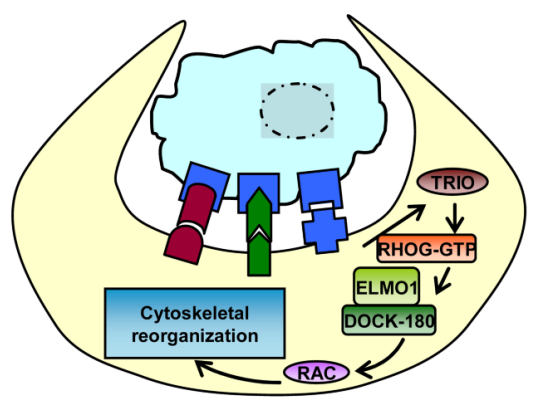

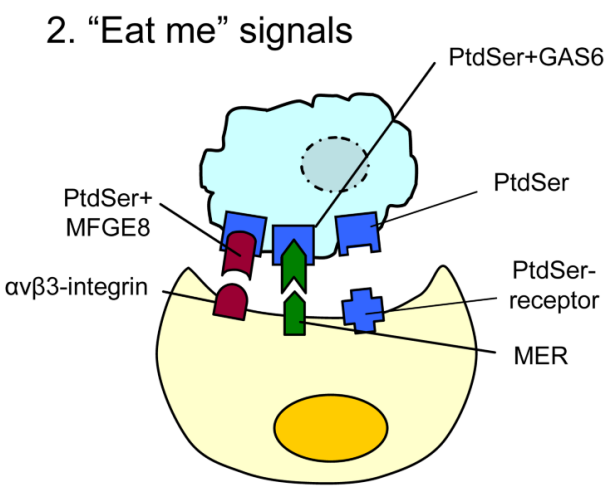

\section{Degradation}

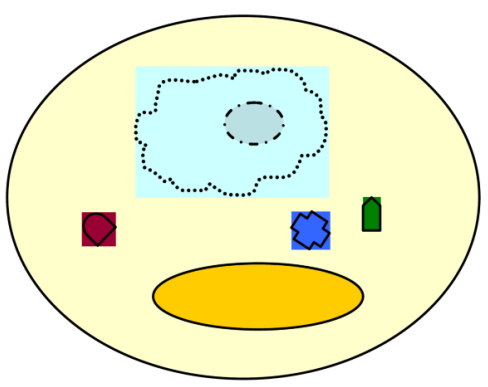

Figure 1. Phagocytosis of apoptotic cells

At the early stages of apoptosis the dying cell releases the "find-me" signals that facilitate the recruitment of phagocytes, it is generally accepted that multiple find-me signals work together in this process but only data about lipid lysophodphatidylcholine (LPC) are found. Apoptotic cells then express membrane eat-me signals which are recognized by phagocyte receptors; phosphatidylserine (PtdSer) is the key receptor in this process and binds mainly the Phosphatidylserine-receptor on the phagocyte. The PtdSercan also be expressed by the apoptotic cell conjugated to milk fat globule EGF factor 8 protein (MFGE8) or growth-arrestspecific 6 (GAS6), which in turn can be recognized by the phagocyte receptors $\alpha_{v} \beta_{3}$-integrin and MER. The cytoskeletal reorganization involves RHO family GTPases (i.e. RAC), ELMO1 (engulfment and cell motility 1), DOCK180 proteins represent one mode of activation. Other modes of activation may also exist (not shown). After internalization, actin is shed from the phagosome and the phagosome matures by a series of fusion and fission events with components of the endocytic pathway culminating in the mature phagolysosome 


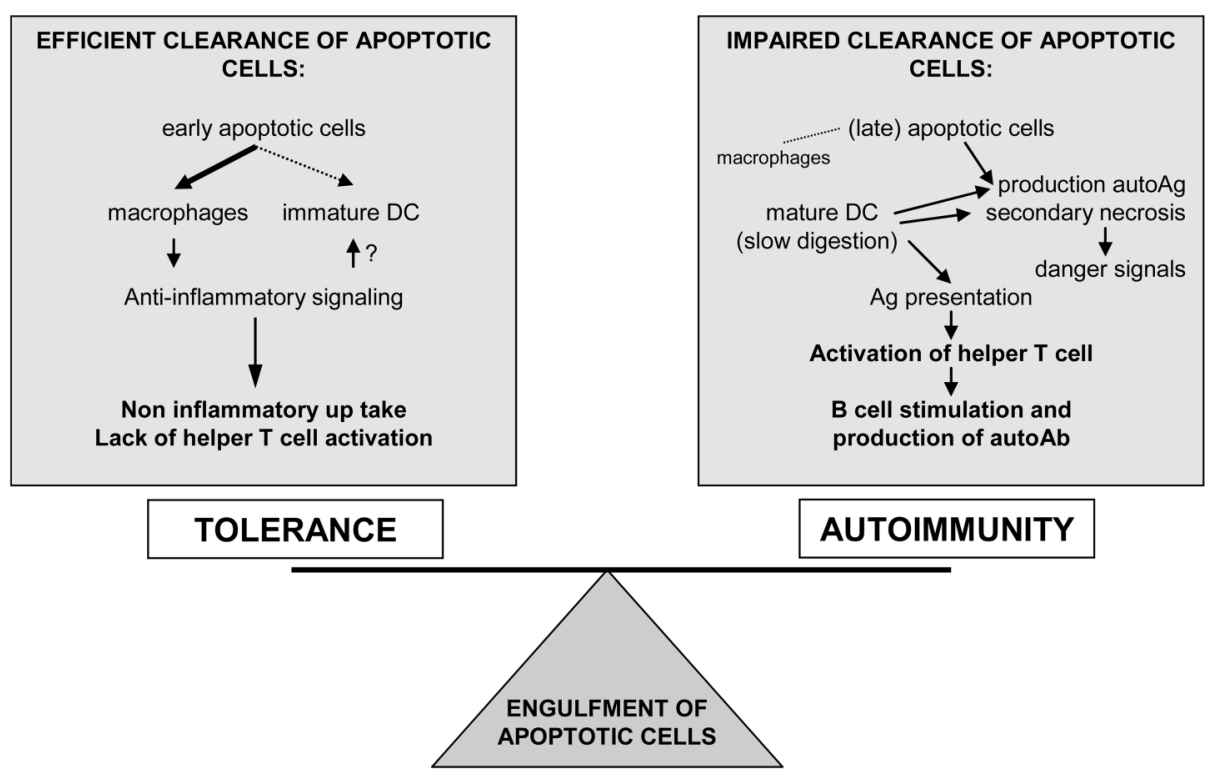

Figure 2.

Consequences of the engulfment of apoptotic cells in the immune system. The uptake of dying cells is usually followed by an anti-inflammatory response and not associated with loss of tolerance. However, an ineffective removal of apoptotic cells is related to generation of "neoantigensf that, presented to the T cells by mature DC can stimulate the production of autoantibodies. Ag: antigen; Ab: antibody; DC: dendritic cell 
Table 1

Characteristics of the immune response induced after cell phagocytosis. AA: arachidonic acid, LPS: lipopolysaccharide

\begin{tabular}{|c|c|c|}
\hline & Necrotic cells & Apoptotic cells \\
\hline \multirow[t]{2}{*}{ Cytokines } & - - Proinflammatory cytokine secretion & $\begin{array}{l}\text { - Inhibition of pro-inflammatory cytokine gene } \\
\text { transcription }\end{array}$ \\
\hline & & $\begin{array}{l}\text { - Anti-inflammatory cytokine secretion: TGF- } \\
\quad \beta, \text { IL-10, IL-13 }\end{array}$ \\
\hline \multirow[t]{3}{*}{ Inflammation } & $\begin{array}{l}\text { - Activation of thromboxane and NO } \\
\text { synthase }\end{array}$ & $\begin{array}{l}\text { - Induction of AA release and prostaglandine } \\
\text { synthase expression }\end{array}$ \\
\hline & - $\quad$ - Activation by LPS & - $\quad$ - Inhibition of thromboxane and NO synthase \\
\hline & - $\quad-\mathrm{CD} 40 \mathrm{~L}$ and $\mathrm{CD} 40$ up regulation & - $\quad$ - CD40L and CD40 down-regulation \\
\hline Dendritic Cells & $\begin{array}{l}\text { - Presentation of exogen antigens to } \\
\mathrm{CD} 4^{+} \text {and } \mathrm{CD} 8^{+} \mathrm{T} \text { cells }\end{array}$ & $\begin{array}{l}\text { - Immune tolerance: silencing } \mathrm{CD} 4^{+} \text {and } \\
\mathrm{CD} 8^{+} \mathrm{T} \text { cells }\end{array}$ \\
\hline
\end{tabular}




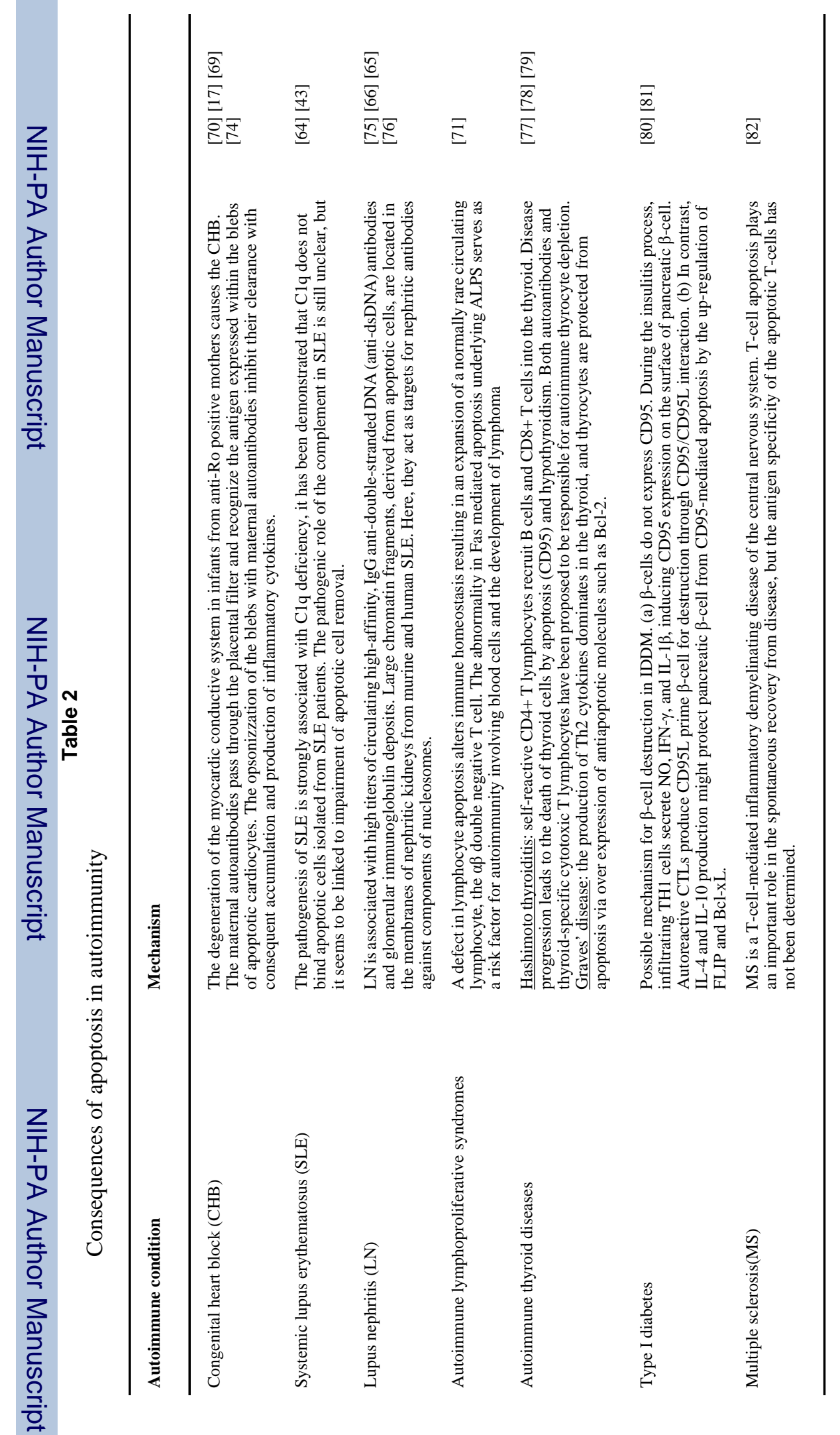

